\title{
The being who being-in-the-world ... becomes mother of a second child
}

\author{
O ser que sendo-no-mundo ... se torna mãe de um segundo filho \\ El ser que siendo-en-el-mundo ... Se convierte en madre de un segundo hijo
}

How to cite this article:

Guarda-Rodrigues J, Rebelo-Botelho MA. The being who being-in-the-world ... becomes mother of a second child. Rev Esc Enferm USP. 2021;55:e20210055. https://doi.org/10.1590/1980-220X-REEUSP-2020-0055

\section{D) Joana Guarda-Rodrigues ${ }^{1}$ \\ iD Maria Antónia Rebelo-Botelho²}

* Extracted from the Doctoral Dissertation: Tornar-se mãe de um segundo filho: a experiência vivida da mulher. Universidade de Lisboa in a collaboration with Escola Superior de

Enfermagem de Lisboa, 2021

${ }^{1}$ Escola Superior de Enfermagem de Lisboa, Departamento da Criança e do Jovem, Lisboa, Portugal

${ }^{2}$ Escola Superior de Enfermagem de Lisboa, Programa de Doutoramento em Enfermagem, Lisboa, Portugal

\begin{abstract}
Becoming mother of a second child, as a parental transition phenomenon, poses a challenge to reflection in Nursing. This theoretical study intends to present a reflection on the being who being-in-the-world becomes mother of a second child. It is based on Heideggerian phenomenology and nursing thought. The text is organized around two axes: Heidegger's conceptual contributions and nursing thought. The Heideggerian ontological dimension, aligned with the humanistic presuppositions of Nursing, contributes to unfold the meanings of life experiences and broaden possibilities of caring of the being who being-in-the-world... becomes mother of a second child. Concomitantly, the access to the experience of women who being-in-the-world become mother of a second child enables widening comprehension of this phenomenon, which will certainly impact nurses' being-present in their daily care.
\end{abstract}

DESCRIPTORS

Mothers; Parenting; Siblings; Family; Nursing. 


\section{INTRODUCTION}

Becoming mother of a second child, as a parental transition phenomenon, is a period of higher vulnerability for persons as "beings-in-the-world"(1-2), in finding their new identity.

The woman as a person, i.e., a "being-in-the-world"(1-2), who being becomes mother of a second child, requires, when living this parental transition, the operationalization of a different professional human care, directed at reinforcing competences and resources, as well as minimizing vulnerability. In other words, care which promotes increased autonomy and capacity of adapting to a new role and being is necessary ${ }^{(3-5)}$.

Although there are several studies and publications focusing on the first parental transition, particularly developed by nurses ${ }^{(4-5)}$, evidence on the transition of women who become mothers of a second child is scarce and outdated, in addition to not providing for a deep comprehension of this human experience from the woman's perspective ${ }^{(4-5)}$.

Also, facilitation of the transition processes is one of the foci of Nursing, in which care emerges as a process which facilitates successful transitions ${ }^{(6)}$. However, professional care demands approximation with reality, with what is experienced and felt by each person in their existence, particularly when undergoing a transitional phenomenon.

Nursing, as a field of study and profession, is based on the conception of person-centered care, whose practice is an art observed in relations with people, in their process of becoming. It considers the person as a human being, a "being-in-the-world" ${ }^{(1-2)}$, in a particular space and time, in which beings who care and who receive care interrelate and become intertwined in an intersubjective dynamic ${ }^{(2)}$.

Nursing is immersed in people's life experiences, which are unique and create their own meanings. The philosophical premises of phenomenology in its approaches, according to which human experience is a valuable source of knowledge, enable dealing with the complexity and depth of human experience as it is lived ${ }^{(7-8)}$.

Paterson \& Zderad introduced phenomenological Nursing as a methodology for understanding the experience of the nurse's encounter with the other through the Humanistic Theory ${ }^{(7)}$. These authors adopt an existential view of Nursing and its phenomena of interest instead of a rationalist and positivist view. Patrícia Benner was also inspired by the existential phenomenology of philosophers such as Maurice Merleau-Ponty and Martin Heidegger, among several other researchers.

In view of the above and understanding the importance of theoretical-philosophical reflection on this phenomenon for a sensitive and humanistic care practice, this study has the objective of presenting a reflection on the being who being-in-the-world becomes mother of a second child through Heideggerian phenomenology and nursing thought. This theoretical-philosophical study is organized into two axes: conceptual contributions of Martin Heidegger and the nursing framework, emphasizing the scientific production on this phenomenon. Explanations and reflections are presented according to literature interpretations, as well as the authors' reflections.

\section{THE BEING WHO BEING-IN-THE-WORLD... BECOMES MOTHER OF A SECOND CHILD}

\section{The Being Who Being-IN-THe-World...}

The ontological dimension, presented in the Heideggerian framework, contributes to unfold the meanings of life experiences and broaden possibilities in nursing care, as this framework demonstrates coherence and alignment with the humanistic principles of Nursing and its object of study, enabling widening possible outlooks on the "being" of humans in their daily lives, promoting comprehension of the being in its several aspects, in their experiences and relations in the world.

In his philosophy, Heidegger classifies the human being as being-in-the-world. For this philosopher, the being is far from what is most evident; quite the opposite: the being is what is most mysterious in existence and, consequently, it deserves to be, firstly, interrogated ${ }^{(1)}$. The philosopher seeks to understand the deepest structure of the human being, i.e., its being. This is his departing point, since through man himself the path to understand the being emerges. It is on the "being-there", the "Dasein", according to Heidegger, that we can find the specific modality of being of the human beings.

For this philosopher, the being can be accessed through the entity, since the being only manifests through the entity, given that "the being is always the being of an entity"(1). However, since the entity includes many things, for everything that is is part of it, an entity, the entity to conduct the question of being must be precisely delimited. Heidegger's choice "is based on the entity which poses the question of being, i.e., about the entity which we are ourselves, and which he names 'Dasein (being-there)"'(9).

However, the human being is not any entity: it has the elementary singularity of always being in relation with the being ${ }^{(1)}$. Heidegger demonstrates a relation of man with himself, that which constitutes the nucleus of human existence, as one single reality, i.e., man as subject of his own making ${ }^{(1)}$.

Man understands himself as the being to whom being itself in factual life is questioned, which is not an objective being among others, but a being present to himself and others through the uncertainty of his own being. This form of the being, in which the being in its all forms is a problem, as previously mentioned, is named by Heidegger as "Dasein (being-there)", also translated as "presence" (10). However, Heidegger clarifies that "presence is not only an entity which occurs among other entities (...) the presence understands itself in its being, being"; thus, the "understanding of being is itself a determination of the presence's being" (1).

Presence emerges, thus, as an entity which, being, puts his own being into play. Man is also understood here to relate, establish relations, being mostly absorbed, taking the shape of his world, the reality he lives in.

For Heidegger, it is in the intimate relation with the being that "man existence" is named, and this "existence" is 
his "essence". Fundamental ontology may thus, "be defined as an existential analytic"(10) or as an "existentiary analytic" of "Dasein"(9); this thought underlies Heidegger's revelation when referring that "The 'essence' of being-there dwells in its existence"(1).

Considering that "being-there" has an original mode of being, distinct of all other entities, namely material things, inanimate beings, or other living beings, which are always "indifferent" to their being, "being-there" refers always to a being who is its own, since "being-there does not 'subsist' only, but it 'exists"'(9). If existing is interpreting oneself and interpreting oneself is questioning oneself, thus, in this questioning, the issue of being is at play.

The world of worry, of daily banality, of the dimensions of active life, of practical action, is the significant horizon where the worried "being-there" meets an entity with which it must deal; and it is in this world that the "being-there" maintains a particular relation with others ${ }^{(9)}$. "Being-there" is as if monopolized by others and is unendingly determined in its relationship with them. As a whole, "being-there, in daily being-with-one-another ("das Miteinandersein"), is under the influence of the other and is deprived of its being itself" ${ }^{(9)}$. Heidegger says that "It is not himself who is", "others take away his being" ${ }^{(9)}$.

For the philosopher, the "starting point of the existentiary analytic is a fundamental structure of being-there: 'beingto-the-world' or 'being-in-the-world' ("In-der-Welt-sein"). Being-in-the-world denotes a single phenomenon which composes several structural moments which are unbreakably connected: the world, the entity which is in the world and the being in..." ${ }^{(9)}$. Being-with-the-world is presented as a "modality of being-in-the-world in which being-there is taken or "captivated" by its world"(9).

Heidegger takes the existential analytic to its limit, showing that "existential structure of factual and daily life is the "being-in-the-world" and that this relation with the world, base of all meaning, is temporal and historical" ${ }^{(10)}$. This context "will enable accessing, from the comprehension of temporality of "Dasein", time apprehension", i.e., time emerges as the "horizon" of the manifestation of being inasmuch as men's being only exists as being in time ${ }^{(10)}$.

"Being-there emerges from the future, in a way that future 'passed' (or better still, 'having-passed') frees the present from itself... This single phenomenon as future having been presentifying" is named temporality by Heidegger ${ }^{(9)}$. Heidegger shows that the being of the entity that we are dwells in temporality ${ }^{(1)}$.

The being and meaning of being as slightly revealed presents an interpretation of time as a horizon of all its comprehension, a being who between birth and death is everyday life. Attending to the fact that apprehension and comprehension of life, as it is humanly lived by people in their daily lives, as beings-in-the-world, is a source of knowledge to Nursing, the study of phenomena comprising it emerges as relevant, particularly referring to the meaning experienced in the context of parental transition ${ }^{(8)}$.

This context encompasses the relevance of the comprehension of being and the meaning of being, who is a woman, and who, being in the present time, returns to the past and projects into the future, becomes mother of a second child. Unfolding this phenomenon enables widening reflection in view of parental transition, experienced by women in their daily lives, contributing to the development of knowledge which maintains Nursing as the human science of care.

\section{THE BEING WHO BEING-IN-THE-WORLD... BECOMES MOTHER OF A SECOND CHILD...}

The woman, who is a person, a "being-in-the-world"(1-2), a being with temporal horizons, a human being who, beingin-the-world-with-others, more concretely with the other, with her special entity, which is her second child - who is also a being-in-the-world -, experiences daily a transitive, complex, lived, transformational trajectory, in which she becomes mother again ${ }^{(11)}$.

The reflection on the near absence of definition of the concept of motherhood, as well as its absence as a descriptor in scientific databases, is relevant, particularly because this is a common phenomenon of human existence. Also, there are few studies describing in depth the experience of this transition for the second time from the woman's viewpoint, not only focusing on pregnancy, postpartum, or the weeks immediately after birth ${ }^{(3-5)}$. A considerable share of studies on second parental transition were published over ten years ago and were conducted predominantly between the nine months of pregnancy and the second child having twelve months of age $\mathrm{e}^{(3-5)}$ with no focus on the experience of women with becoming mother of a second child ${ }^{(5)}$; additionally, it is recognized that becoming mother of a first and second child are different, singular experiences from a qualitative viewpoint.

In this context, it is relevant to present here the theoretical-conceptual evolution identified in the scientific production. In 1967, Rubin named "maternal role attainment" the process which conducts women in their conquest of a new identity regarding their maternal role, in which progressive stages are included, such as mimicry, role-play, fantasy, introjection, projection, rejection, and identity ${ }^{(11)}$. These stages are started during pregnancy and finish when women present, on the one hand, the sensation of being in their role and, on the other hand, comfort regarding their past and future.

However, for the author, maternal identity is more than a role which can be applied and removed: it comes from an inseparable incorporation in the whole of personality. According to the author, identity, behavior, and the quality of life of mother and family evolve according to age changes, and in the condition and situation of the child, i.e., each pregnancy experience is different, as are the setting of a woman's life and her self ${ }^{(11)}$. Thus, the singularity of each child, in that specific moment of the woman's life, requires systematic and extensive maternal work to understand and incorporate the child to their own systems and into family. Thus, with the birth of each subsequent child, a new personal dimension is incorporated into the woman's system, with no transference of maternal identity from one child to another.

Mercer, a disciple of Rubin, started various studies focusing on "maternal role attainment" in singular situations 
in the first 8 to 12 months of pregnancy, verifying that, although the last stage was related to maternal identity, the dynamic transformation and evolution of women's personalities were not duly grasped through this concept, inasmuch as the continuous expansion of the $\mathrm{I}$ as a mother was not included ${ }^{(11)}$. This argument leads the author to suggest the substitution of "maternal role attainment" by "becoming a mother" to denote the initial transformation and continuous growth of maternal identity ${ }^{(11)}$.

The main concepts of Mercer's theory on "maternal role attainment/becoming a mother" are based on the premise that maternal role is particular to the mother who experiences it, may be influenced by diverse mother and child variables, and is a continuous process which may take months or years to be complete ${ }^{(11)}$. This process may be divided into four main steps which frequently overlap: (a) pregnancy, in which the mother acquires a feeling of compromise with the child and starts to anticipate its arrival; (b) the initial postpartum period, which lasts from birth to six weeks of age and is characterized by the mother's familiarization with the child and the start of the learning concerning the presented cues; (c) the establishment of a new normal as the infant becomes part of family dynamics and daily life of father and mother; and (d) eventual obtention of maternal identity ${ }^{(11)}$. This moment occurs around four months of age, when the mother becomes confident on her capacity of providing care and feels happy.

The International Council of Nurses, through the International Classification For Nursing Practice, considers "Ability to Parent" and "Parenting" as foci with relevance for nursing intervention, defining Parenting as: "Caretaking: Taking on responsibilities of being parent(s); behaviours to facilitate the incorporation of a newborn into a family unit; behaviours to optimise growth and development of children; internalising expectations held by individuals, families, friends, and society regarding appropriate or inappropriate role behaviours of being parents"(12).

In 2016, the International Council of Nurses introduced the focus "Mother role", defining it as: "Parent Role: Interacting according to responsibilities of being mother; internalising the expectation held by family members, friends, and society regarding appropriate or inappropriate role behaviours of pregnant women and mothers" ${ }^{\prime(12)}$.

Becoming a mother, although a possibly predictable life happening, implies reorganization and adaptation due to all changes that are associated to $\mathrm{it}^{(11)}$, and we conceive it as a phenomenon that goes far beyond motherhood as the act of being a progenitor. Motherhood, more visible in the child's first years, is understood here as the process of becoming mother, i.e., an interactive and evolutional process which is beyond pregnancy and in which the woman bonds with the child, developing competences related to her role while experiencing gratitude and pleasure ${ }^{(11)}$. This complex individual progression is unique for each mother and each child ${ }^{(11)}$.

The phenomenon of becoming a mother leads to a complex trajectory, which involves conscious and unconscious identifications, contemplating a dynamic evolution and transformation of people and their own selves in the search for their new identity ${ }^{(11)}$. This is a transition for new roles and responsibilities, being critical due to its permanence and irreversibility ${ }^{(11)}$.

The process of becoming a mother requires extensive psychological, social, and physical work. In this transition, women are exposed to increased vulnerability and experiences intense challenges. Vulnerability, as an ontological condition of the human being, may be worsened by experiences of a transition process. Thus, in this time of vulnerability due to assuming a new mother identity, nurses have the opportunity of helping women learn and acquire confidence in their competences.

Transition is, in this context, defined as changing from one phase, condition, or state to another, possibly expressing a change in health status, expectations, role relations, or competences of the human person ${ }^{(6)}$. Thus, transition, considered in its essence as positive, leads people to incorporation of a new knowledge, changing their behaviors to achieve higher stability in relation to the previous period, influencing thus on a new definition of self ${ }^{(6)}$.

Since parenting is considered a transition, the presence of a second child emerges as parental transition ${ }^{(3-5)}$, which involves knowledge and acquisition of skills related to childcare, based on taking parent roles, in the adjustment of the couple and in the parents-child relation so as to include another person ${ }^{(3-5)}$. The facilitation of transition processes is an attention focus in the Nursing area, in which care emerges as a process which facilitates successful transitions ${ }^{(6)}$.

Becoming the mother of a second child, as parental transition, emerges from an adaptive trajectory and from a (re)encounter with a new balance ${ }^{(3,4)}$, marked by the start of a fraternal sub-system, in which interaction complexity is increased, requiring a reorganization of the established family system, in which the acceptance of children by other relatives is one of the most important challenges that women have to face ${ }^{(13-14)}$. From this moment on, there is not only the relationship between the couple, but also the parentschildren relationship and the relationship among siblings ${ }^{(13)}$; the first child is born to a couple, but the second child is born to a family. Scientific production seems to point out that the main impact of pregnancy and birth of a second child is experienced in relation to the mother, although it may also have an impact on other intervening people ${ }^{(13)}$.

The woman, who being becomes mother of a second child, must prepare for the adjustment and arrival of another child, continuing to care and manage the adjustment of the oldest child. Feelings of ambivalence, sadness, and guilt, in a way related to mourning due to a reduction in the intensity of the relation with the first child, are referred by women who experience this transition ${ }^{(13)}$; these women also questioned themselves on their capacity of balancing their time and love between the two children. These women tend to report more stress than first-time mothers or mothers with three or more children ${ }^{(3-4)}$. This maternal stress seems to derive both from the referred difficulties of taking care of a first child and a constellation of factors which are inherent to the mother's relationship with her partner, with her or their labor status. The scientific production highlights that, while 
experiencing this transition, gender roles may be accentuated and contribute to a higher overload of women, matching the increased complexity of daily tasks and requiring adjustment and redefinition of intervening people.

In this adaptive path towards balance, women must feel supported to provide their sensible presence ${ }^{(3)}$. The type of relationship with the partner and domestic overload are described as influencing couple satisfaction and maternal well-being ${ }^{(5)}$. Some authors emphasize that complementarity between partners facilitates the mother's welcoming of the second child and redefinition of the maternal role ${ }^{(3)}$.

In this transition, beyond the nuclear family system, it is also necessary to account for other resources, namely extended family, health institutions, neighbors, friends, and others. These are possible support resources which can be relevant during routine or troubled moments ${ }^{(14)}$.

Also determinant in this part of the cycle of life are personal characteristics of women, children, family, society, and their environments, i.e., relations and interactions she establishes and the several roles she performs and which conditionate their responses and strategies in this experience ${ }^{(11)}$.

In professional activities, these women, who being became mothers for the second time, are assumed to have fewer needs due to having a previous experience and knowledge on how to respond to the child, and specific interventions inherent to the fact that these are people undergoing a complex and unique moment of their existence are not contemplated. Nursing consultations are based on priorities and the most formal courses tend to focus particularly on the review of the labor process and childbirth and advice on the relationship of the first and second child. Also, the literature does not clarify whether these aspects of this transition are the most important to meet ${ }^{(5)}$.

The experience of this parental transition demands an operationalization of professional human care to help people acquire more autonomy and capacity of adaptation to the new role. Nursing, as a profession mainly designed for care, which entails following major moments in life, as defended by Colliére, finds a focus in the birth of a child. The identification of specific worries of women and the available resources to respond to these worries and minimize their vulnerabilities, as well as the reinforcement of care competences, are relevant for promoting the sense of competence of the mother and the development of her maternal identity. Nurses, during this transition, are in a privileged position, with significant long-term positive repercussions to women.
In light of this, it is relevant to unveil the experience of the woman who, being-in-the-world, becomes mother of a second child, accessing the singularity of the lived world(s) and accounting for the centrality of the person, so as new forms of providing care in nursing, meeting the complexity as well as the singularity of human beings, can be found.

Phenomenology is, in this convergence, the path through which it will be possible to have access to the experiences ${ }^{(8)}$ of the woman who being-in-the-world becomes mother of a second child, and which will certainly provide nurses with the possibility of becoming (even more) attentive and reflexive professionals in daily woman care.

\section{FINAL CONSIDERATIONS}

It is in the daily experience of women as beings who (co) exist in the world, who being become mother of a second child, as a person experiencing this in a unique and singular way, that a source of knowledge which reveals that which is shown will be found, as it shows from itself, enlightening the comprehension of this phenomenon. In other words, in the existence of "being-there", in "Dasein", in women as beings who being become mother of a second child, that truth emerges and shows itself, acknowledging the fact of being-in-theworld in presence, in daily life and inter-relation with others, going beyond oneself, transforming and finding out their own meaning to being human, revealing a possible comprehension of that which truly unveils, becoming present to the other.

Phenomenology, seeking to describe this phenomenon as it manifests to conscience, or better still, emerging as a systematic attempt at unveiling experience, constitutes an access path. The ontological dimension, presented in the Heideggerian framework, aligned with the humanistic principles of Nursing, enables unveiling the meanings of experience and broadening the possibilities of nursing care.

Phenomenologically investigating the human experience of the woman who being becomes mother of a second child, in a singular way and as it is lived, will promote the revealing of this phenomenon of parental transition experienced by women, producing knowledge to sustain the nursing discipline and profession. Access to the essential structure of the phenomenon will enable scaffolding the horizon of comprehension and reflection of nurses regarding person-centered care, or better still, care which is centered on the woman who being-in-the-world becomes mother of a second child, meeting their complexity, as well as their singularity, shedding thus light on the process of decision-making, which is inherent to an evidence-based nursing practice.

\section{RESUMO}

Tornar-se mãe de um segundo filho, enquanto fenómeno de transição na parentalidade, configura-se como um desafio à reflexão em Enfermagem. Pretende-se neste estudo teórico apresentar uma reflexão sobre o ser que sendo-no-mundo se torna mãe de um segundo filho à luz da fenomenologia heideggeriana e do pensamento de enfermagem. $\mathrm{O}$ texto foi organizado em torno de dois eixos: os contributos conceptuais de Heidegger e o pensamento de enfermagem. Identifica-se que a dimensão ontológica heideggeriana, alinhada com os pressupostos humanísticos da Enfermagem, contribui para desvelar os sentidos do vivido e ampliar as possibilidades de cuidar do ser que sendo-no-mundo... se torna mãe de um segundo filho. Concomitantemente, o acesso à experiência da mulher que sendo-nomundo se torna mãe de um segundo filho permite abrir o horizonte de compreensão face ao fenómeno, o que certamente terá impacto no modo de ser-presente do enfermeiro no quotidiano de cuidados.

Mães; Poder Familiar; Irmãos; Família; Enfermagem. 


\section{RESUMEN}

Convertirse en madre de un segundo hijo, en tanto que fenómeno de transición a la parentalidad, se configura como un desafío a la reflexión de Enfermería. Este estudio teórico pretende presentar una reflexión sobre el ser que, siendo-en-el-mundo, se convierte en madre de un segundo hijo a la luz de la fenomenología heideggeriana y del pensamiento enfermero. El texto se organizó en torno a dos ejes: las contribuciones conceptuales de Heidegger y el pensamiento enfermero. Se identifica que la dimensión ontológica heideggeriana, junto con los presupuestos humanísticos de la Enfermería, contribuyen a desvelar los sentidos de lo vivido y a ampliar las posibilidades de cuidar al ser que, siendo-en-el-mundo... se convierte en madre de un segundo hijo. Concomitantemente, el acceso a la experiencia de la mujer que, siendo-en-el-mundo, se convierte en madre de un segundo hijo, permite abrir el horizonte de comprensión del fenómeno, lo que sin duda repercutirá en el modo de ser-presente de los enfermeros en sus cuidados diarios.

\section{DESCRIPTORES}

Madres; Responsabilidad Parental; Hermanos; Familia; Enfermería.

\section{REFERENCES}

1. Heidegger M. Ser e tempo. Petrópolis: Editora Vozes; 2009.

2. Watson J. Human Caring Science: A Theory of Nursing. Sudbury: Jones and Bartlett Publishers; 2011.

3. O'Reilly M. Achieving a new balance: women's transition to second-time parenthood. JOGNN J Obstet Gynecol Neonatal Nurs [Internet]. 2004 [cited 2020 Dec 10];33(4):455-62. Available from: http://search.ebscohost.com/login.aspx?direct=true\&db=rzh\&AN= $106656964 \&$ site $=$ ehost-live.

4. Rodrigues J, Botelho MA. Transição para o Segundo Filho: da Saúde às Políticas Públicas. Ciências e Políticas Públicas [Internet] 2020 [cited 2021 June 30];VI(1):139-57. Available from: https://capp.iscsp.ulisboa.pt/images/CPP/V6N1/Final/4-PT_V6_N1_online.pdf.

5. Rodrigues J, Velez M. Tornar-se mãe de um segundo filho: uma revisão scoping. Pensar Enferm [Internet]. 2018 [cited 2020 Nov 1]; 22(1):5-17. Available from: http://pensarenfermagem.esel.pt/files/3.

6. Schumacher KL, Meleis Al. Transitions: A central concept in nursing. In: Meleis Al, editor. Experiencing Transitions: an Emerging MiddleRange Theory. New York: Springer Publishing Company; 2010. p. 38-51.

7. Paterson J, Zderad L. Humanistic Nursing [Internet]. Salt Lake: Project Gutenberg; 2008 [cited 2020 Aug 10]. Available from: http:// www.gutenberg.org/cache/epub/25020/pg25020.html.

8. van Manen M. Researching lived experience, human science for an action sensitive pedagogy. 2nd ed. Ontario: The Althouse Press; 1997.

9. Boutot A. Introdução à filosofia de Heidegger. Mem Martins: Europa-América; 1993.

10. Trotignon P. Heidegger. Lisboa: Edições 70; 1990.

11. Mercer RT. Becoming a mother versus maternal role attainment. In: Meleis Al, editor. Transitions Theory: Middle Range and Situation Specific Theories in Nursing Research and Practice. New York: Springer Publishing Company; 2010. p. 94-104.

12. Conselho Internacional de Enfermeiros. CIPE® Versão 2015 - Classificação Internacional para a Prática de Enfermagem. Genebra: Lusidacta; 2016.

13. Piccinini C, Pereira C, Marin A, Lopes R. O Nascimento do Segundo Filho e as Relações Familiares. Psicol Teor e Pesqui [Internet]. 2007 [cited 2020 Aug 1] ;23(3):253-61. Available from: http://www.scielo.br/pdf/ptp/v23n3/a03v23n3.pdf.

14. Pereira C, Piccinini C. O impacto da gestação do segundo filho na dinâmica familiar. Estud Psicol. 2007;24(3):385-95. DOI: https:// dx.doi.org/10.1590/S0103-166X2007000300010. 